\title{
Corrigendum: Hydrogel microphones for stealthy underwater listening
}

Yang Gao, Jingfeng Song, Shumin Li, Christian Elowsky, You Zhou, Stephen Ducharme, Yong Mei Chen, Qin Zhou \& Li Tan

Nature Communications 7:12316 doi: 10.1038/ncomms12316 (2016); Published 24 Aug 2016; Updated 28 Sep 2016.

The financial support for this Article was not fully acknowledged. The Acknowledgements should have included the following: Y.M.C. gratefully acknowledges the financial support from International Science and Technology Cooperation Program supported by National Natural Science Foundation of China (No. 11674263).

(c) This work is licensed under a Creative Commons Attribution 4.0 International License. The images or other third party material in this article are included in the to obtain permission from the license holder to reproduce the material. To view a copy of this license, visit http://creativecommons.org/licenses/by/4.0/

(C) The Author(s) 2016 